\title{
Polychaete Ecology and Niche Patterns: Texas Continental Shelf*
}

\author{
R. Warren Flint and Nancy N. Rabalais \\ University of Texas Marine Science Institute, Port Aransas Marine Laboratory, Port Aransas, Texas 78373, USA
}

\begin{abstract}
South Texas continental shelf benthic polychaetes were studied over a two-year period to characterize their ecological patterns. Polychaetes are the dominant infauna of this shelf environment, comprising $74 \%$ of all infaunal abundance. The 14 polychaete species chosen for study illustrated distinct niche patterns based upon their various preferences mainly for certain sediment types and less for the degree of bottom water environmental stability. Some of those species shown through multivariate discriminant analysis still to prefer similar habitats, had their specific niche properties further defined through classification into certain feeding strategies that these polychaetes are assumed to exhibit. Through this exercise of combining environmental data with species occurrences and the behavioral characteristics of these species, the abundant infaunal polychaete species of the south Texas shelf were found to exhibit niche structures that contribute considerable information concerning the roles of these species in the benthic community. Furthermore, these species could be classified as either generalists or specialists within their habitat.
\end{abstract}

\section{INTRODUCTION}

Ecologists have long been intrigued by differences in habitat and life history of closely related species. This interest has focused on differences in the way species in the same community utilize resources. The definition of these communities, especially along environmental gradients (i. e. soil type, altitude, water depth) is normally accomplished by a subjective method of numerical classification (i. e. ordination, cluster analysis). After the subjective definition of discrete assemblages of organisms, it is valuable and often necessary to identify the resource partitioning that exists within a community, to aid in explaining the coexistence of ecologically similar species.

Hutchinson's (1957) reformulation of the concept of ecological niche provides a precise definition for the description of resource partitioning. He proposed that a species' population could be characterized by its position along each of a set of a few independent dimensions, ordering environmental variables. In a more recent attempt to clarify the use of the term niche, Whittaker et al. (1973) restricted their definition to

- University of Texas Marine Science Institute Contribution No. 402

(c) by Inter-Research include intracommunity variables that are both intensive and local, as well as a population response to these variables. That part of hyperspace that each species in the community utilizes, occupies, or is affected by, is the niche hypervolume (Makarewicz and Likens, 1975). Within this n-dimensional space, the species' population response to the environmental variables provides the best characterization of the niche.

In the past analysis of niche relationships in natural communities by painstaking observation has proved to be a long and tedious exercise (e. g. MacArthur, 1968; Cody, 1968). Maguire (1967) proposed using multivariate discriminant functions to more easily define niche properties of a species, revealing greater generality at the expense of detail. Several recent investigations involving the study of species' populations arranged in ecological categories have utilized discriminant function analysis with reasonable success (e. g. Green, 1974; M'Closky, 1976; Dueser and Shugart, 1978, 1979). A good explanation of the reasons for using discriminant analysis as a quantitative representation of such niche concepts as breadth and overlap in an ndimensional space, as well as the assumptions to be considered, can be found in Green (1974) and Dueser and Shugart (1979). 
Flint and Rabalais (1980) used numerial species data to define geographic ecological categories (communities) on the Gulf of Mexico continental shelf off south Texas. The environmental differences in intercommunity habitats were identified using discriminant analysis. These discrete assemblages were distributed along an environmental gradient influenced by both sediment type and degree of bottom water environmental stability. The present manuscript focuses on the nearshore assemblage and examines the niche characteristics of several polychaetes, which are the most abundant organisms in this community.

The major objective of this study was to apply the method of discriminant function analysis, previously used on terrestrial ecosystems (Dueser and Shugart, $1978,1979)$, to the continental shelf seafloor which is a more complicated system in both number of species and environmental heterogeneity. An attempt was made to (1) define the resource partitioning for the abundant polychaetes comprising the nearshore community, (2) reduce the multivariate nature of the data to a few interpretable dimensions, (3) evaluate the intracommunity polychaete relationships in terms of niche breadth and overlap, and (4) consider the resource partitioning by these species in terms of their functional characteristics (e.g. feeding strategies) within the community.

\section{STUDY AREA AND METHODS}

The general characteristics of the study area, the community structure of the nearshore benthos, and the sampling methods are reported elsewhere (Flint and Holland, 1980; Flint and Rabalais, 1980; Rabalais et al., in press). Collections of benthic macroinfauna were taken at six stations within a $2800 \mathrm{~km}^{2}$ area on the south Texas continental shelf in water depths from 10 to $27 \mathrm{~m}$. The seafloor is characterized by fairly wellsorted sediments predominantly comprised of fine sands but also mixed with considerable amounts of shelf mud $(20$ to $50 \%)$. The sediments are often subjected to high-energy features including wave action and strong longshore currents that often disturb and redistribute the muddy sands. In addition, bottom water hydrographic features, including salinity and temperature, show considerable temporal variability. Benthic macroinfauna were sampled with a SmithMcintyre grab $\left(0.1 \mathrm{~m}^{2}\right.$ ) on a seasonal basis (winter, spring, and fall) for two years (1976-1977). Sampling included six replicate grabs at each station during each collection period. Data reported here are from a total of 216 grab samples taken during the study period at the six nearshore stations $(4 / \mathrm{I}, 1 / \mathrm{I}, 1 / \mathrm{II}, 4 / \mathrm{III}, 4 / \mathrm{TV}$, and $1 / \mathrm{TV}$ ), a subset of the total 25 stations on the south Texas continental shelf reported on elsewhere (Flint and Rabalais, 1980; Rabalais et al., in press).

Environmental variables were selected to provide measures of habitat structure that best characterized each polychaete species. In total, 16 variables were measured for each benthic grab and included 10 sediment texture measures, bottom water temperature, salinity, and dissolved oxygen, water depth, sediment total organic carbon, and the sediment delta ${ }^{13} \mathrm{C}$ measure. Because many of these variables were either (1) significantly correlated, violating assumptions of the multivariate analysis technique chosen, or (2) were conceptually similar, a subset of eight important variables was selected for multiple discriminant analysis. These included the sediment texture variables, grain size sorting, percent sand, percent silt, sand/mud ratio, silt/clay ratio, measured according to the Wentworth sediment grade classification (Buchanan and Kain, 1971), and the additional variables, bottom water salinity standard deviation (STD), water depth, and sediment total organic carbon. Each of these variables is seasonally stable and produced an F-value significant at $P<0.01$ in an initial univariate analysis of variance for overall species differences. Each variable, in addition, had a correlation of less than 0.80 with any other variable chosen, which was within the limits recommended by Mattson et al. (1977). Thus this subset contained the least redundant variables that had power to discriminate among polychaete species.

Multivariate discriminant analysis, following routines from Cooley and Lohnes (1971), was employed to evaluate the environmental characteristics of each polychaete species niche. The observation vector included a sample group representing each species, each group containing from 43 to 208 cases, and eight environmental variables. The test of the data for meeting the assumption of equality of species variance-covariance matrices rejected the null hypothesis of homogeneity of these matrices $(P<0.01)$. This result indicated that the multivariate dimensions representing the polychaete species examined, differed significantly in size and shape, regardless of position in the sample space. The test of the null hypothesis for equality of species centroids in the multidimensional space was not, therefore, strictly valid (Green, 1974).

Nevertheless, discriminant analysis was viewed as the best means of defining the habitat characteristics of these polychaete species. Thus, the ecological significance of each discriminant function was judged according to the following: (1) could it be interpreted in an ecologically meaningful manner, and (2) did it provide obvious separation of at least two species, consistent with the discriminant function interpretation of Green (1974)? 


\section{RESULTS}

Polychaetes comprised approximately $74 \%$ of the total macroinfaunal ( $>0.5 \mathrm{~mm}$ ) density in these coastal waters. Fourteen of the most abundant polychaete species were chosen for study (Table 1). Their density represented $64 \%$ of the total polychaete abundance and $48 \%$ of the total macroinfaunal abundance. The species represented several feeding strategies including active scavengers, surface deposit feeders, and burrowing subsurface deposit feeders.

Magelona phyllisae was the most abundant polychaete observed (Table 1). This species along with Lumbrineris verrilli, Mediomastus californiensis and Paraprionospio pinnata occurred at each of the 6 stations during at least one collection period in greater than $2 \%$ of total infaunal abundance for those stations. The other 10 polychaetes occurred at a minimum of at least 3 of the 6 stations sampled during the study period in greater than $2 \%$ of total infaunal abundance.

Table 1. Total abundances and number of occurrences of polychaete ${ }^{1}$ species in a total of 216 grab samples taken during the study period on the nearshore south Texas continental shelf. The 14 polychaete species comprise $64 \%$ of the total polychaete abundance and $48 \%$ of the total infaunal (> $0.5 \mathrm{~mm}$ ) abundance

\begin{tabular}{|c|c|c|}
\hline $\begin{array}{l}\text { Polychaetes } \\
\text { Family, species }\end{array}$ & $\begin{array}{c}\text { Total } \\
\text { abundance }\end{array}$ & $\begin{array}{l}\text { Number of } \\
\text { occurrences }\end{array}$ \\
\hline \multicolumn{3}{|l|}{ Pilargiidae } \\
\hline Litocorsa stremma & 977 & 105 \\
\hline \multicolumn{3}{|l|}{ Nereidae } \\
\hline Nereis micromma & 1,167 & 190 \\
\hline \multicolumn{3}{|l|}{ Lumbrineridae } \\
\hline Lumbrineris verrilli & 6,386 & 181 \\
\hline \multicolumn{3}{|l|}{ Spionidae } \\
\hline Paraprionospio pinnata & 3,893 & 211 \\
\hline Spiophanes bombyx & 1,263 & 81 \\
\hline Prionospio steenstrupi & 612 & 43 \\
\hline \multicolumn{3}{|l|}{ Magelonidae } \\
\hline Magelona phyllisae & 13,366 & 204 \\
\hline Magelona pettiboneae & 1,349 & 126 \\
\hline \multicolumn{3}{|l|}{ Cirratulidae } \\
\hline Tharyx spp. & 1,994 & 122 \\
\hline \multicolumn{3}{|l|}{ Paraonidae } \\
\hline Paraonides lyra & 1,768 & 108 \\
\hline Aricidea taylori & 961 & 122 \\
\hline \multicolumn{3}{|l|}{ Cossuridae } \\
\hline Cossura delta & 503 & 178 \\
\hline \multicolumn{3}{|l|}{ Capitellidae } \\
\hline Mediomastus californiensis & 4,686 & 199 \\
\hline \multicolumn{3}{|l|}{ Oweniidae } \\
\hline Owenia fusiformis & 876 & 83 \\
\hline $\begin{array}{l}1 \text { Polychaetes comprise } 74 \% \\
\text { abundance }\end{array}$ & of the total $\mathrm{m}$ & arrninfaunal \\
\hline
\end{tabular}

These occurrences represented at least 2 of the 6 sampling periods of study.

Considerable overlap (co-occurrence) often occurred between the polychaete species with several different species observed in the same replicate grab samples. In addition to the occurrences, patterns in density of the different populations at a station were often recognized. For example, Litocorsa stremma densities were correlated with those population densities for Magelona phyllisae $(r=0.44 ; n=144)$, Paraonides lyra $(r=0.48 ; n=144)$, Mediomastus californiensis $(r=0.56 ; n=144)$ and Owenia fusiformis $(r=0.47$; $n=144)$, all of which were significant $(P<0.001)$. Lumbrineris verrilli population densities were correlated with Magelona pettiboneae $(r=0.40 ; n=144)$, and $M$. californiensis $(r=0.49 ; n=141)$, while $P$. lyra was related to the densities of $M$. californiensis ( $r=$ $0.51 ; n=135)$. $M$. californiensis population densities were related to Magelona phyllisae $(r=0.46 ; n=$ 144), $M$. pettiboneae $(r=0.51 ; n=135)$, and Spiophanes bombyx $(r=0.43 ; n=141)$. Nereis $m i$ cromma, in contrast to $L$. stremma, exhibited negative correlations with two other polychaete populations, Magelona phyllisae $(r=-0.44 ; n=144)$ and Aricidea taylori $(r=-0.46 ; \mathrm{n}=141)$, both of which were again significant $(P<0.001)$.

\section{Niche Separation}

As would be expected, from the initial screening of environmental variables for use in discriminant analysis that showed species differences in a univariate test, the 14 polychaete species did not show a common centroid (Fig. 1). They differed in position as well as size and shape in the space defined by the first two discriminant function vectors. Based on this observation, we proceeded with the evaluation of the results because the functions produced from the discriminant analysis were ecologically interpretable and contributed to species separation in the sample space (Fig. 1).

Discriminant function 1 (DF1) accounted for $75.2 \%$ of the discriminating information in the environmental variables; DF2 accounted for an additional $18.3 \%$ (Table 2). Both of these discriminant functions were significant $(P<0.001)$ in discriminating between species (Table 2) while DF3 was not, and therefore not included in the results. Each discriminant function can be represented graphically as an independent, normalized discriminant axis, as illustrated in Fig. 1. The discriminant function standardized coefficients for the variables (Table 2) are combined with the individual measured values of these variables for each species case to produce a point in the discriminant space known as the discriminant score for that species case. 


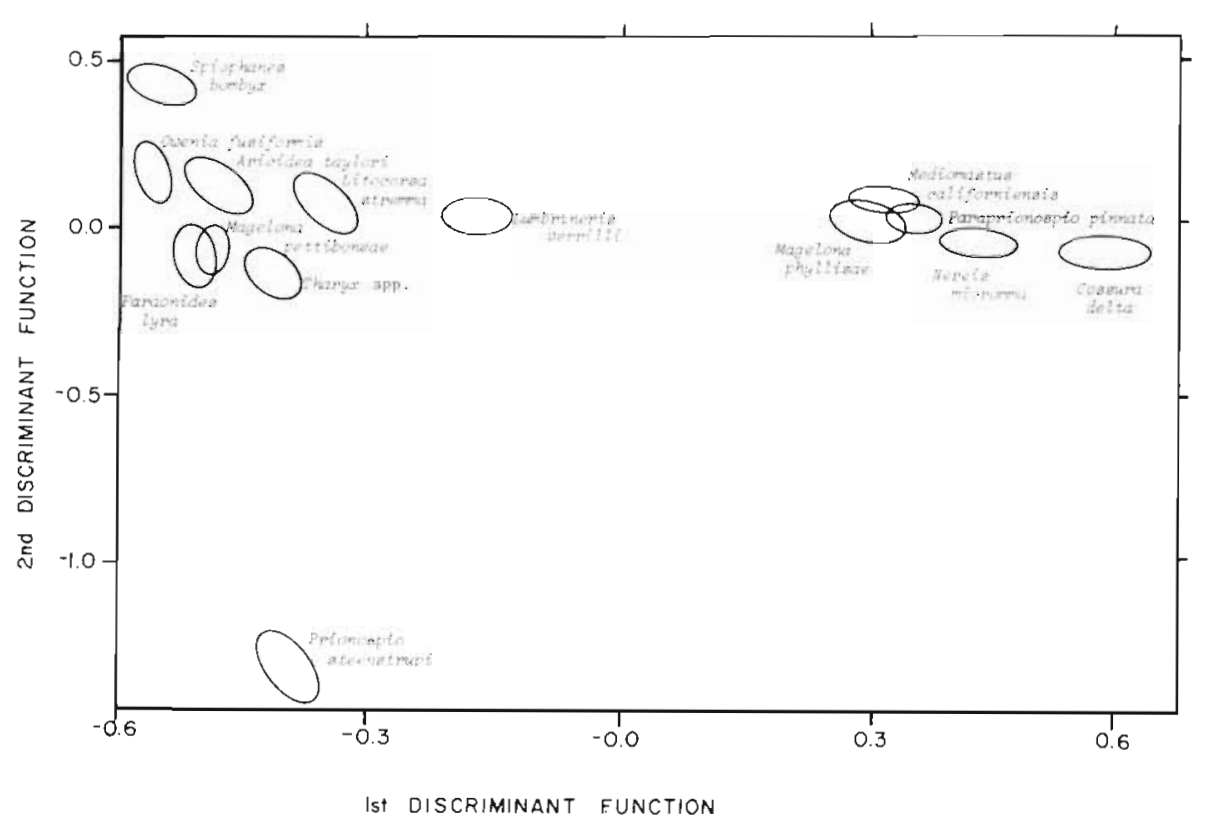

Fig. 1. Ninety-five percent confidence ellipses for the polychaete species' mean discriminant scores on discriminant Functions (Axis) 1 and 2. These confidence regions were calculated from the discriminant score means, variances and covariances using the principal axis technique of Sokal and Rohlf (1969)

Until recently, the standardized coefficients were used to interpret the ecological meaning of each DF axis (e.g. Knight, 1974; Green, 1977; Bernstein et al., 1978). Dueser and Shugart (1979), however, chose to use the correlation between the discriminant function score and each of the measurement variables, which as they illustrated did not necessarily convey the same rank of importance as the standardized coefficents. We used this same approach but evaluated the correlations in a multivariate process using regression analysis.

The results (Table 2) illustrated that percent sand was the predominant variable in DF1. Percent silt $(0.97)$ and the sediment sand/mud ratio $(-0.78)$ were also important discriminating variables for this DF. The predominant environmental variables for DF2 were bottom water salinity STD and water depth (Table 2). Percent silt again was pinpointed by the regression analysis as being an important discriminat-

Table 2. Summary of multivariate discriminant analysis and correlation of discriminant scores with environmental variables that potentially characterize the niche of 14 polychaetes studied on the south Texas continental shelf

\begin{tabular}{|c|c|c|c|c|c|c|c|c|}
\hline & & & \multicolumn{3}{|c|}{ Discriminant function 1} & \multicolumn{3}{|c|}{ Discriminant function 2} \\
\hline \multirow{4}{*}{\multicolumn{3}{|c|}{$\begin{array}{l}\text { Degrees of freedom } \\
\text { Chi-Square test for significance of DF } \\
\text { Cannonical correlation } \\
\text { Percent explained discrimination }\end{array}$}} & & \multicolumn{3}{|c|}{84} \\
\hline & & & \multicolumn{3}{|c|}{$548.3^{*}$} & \multicolumn{3}{|c|}{$144.3^{\cdots}$} \\
\hline & & & \multicolumn{3}{|c|}{0.424} & \multicolumn{3}{|c|}{0.225} \\
\hline & & & \multicolumn{3}{|c|}{75.2} & \multicolumn{3}{|c|}{18.3} \\
\hline & \multicolumn{4}{|c|}{ DF1 } & \multicolumn{4}{|c|}{ DF2 } \\
\hline & $\begin{array}{l}\text { Standardized } \\
\text { coefficient }\end{array}$ & $\begin{array}{c}\text { Linear } \\
\text { correlation } \\
\text { coefficient }(r)\end{array}$ & $\begin{array}{l}\text { Multiple } \\
R^{2}\end{array}$ & $\begin{array}{l}\text { Regression } \\
\text { step No. }\end{array}$ & $\begin{array}{c}\text { Standardized } \\
\text { coefficient }\end{array}$ & $\begin{array}{l}\text { Linear } \\
\text { correlation } \\
\text { coefficient }(r)\end{array}$ & $\underset{R^{2}}{\text { Multiple }}$ & $\begin{array}{c}\text { Regression } \\
\text { step No. }\end{array}$ \\
\hline Percent sand & -0.46 & -0.98 & 0.95 & 1 & -0.22 & - & - & - \\
\hline Percent silt & 0.76 & 0.97 & 0.98 & 2 & 0.24 & 0.08 & 0.96 & 3 \\
\hline Sand/mud ratio & 0.19 & -0.78 & 0.99 & 3 & 0.28 & 0.24 & 0.98 & 4 \\
\hline $\begin{array}{l}\text { Bottom water } \\
\text { Salinity STD }\end{array}$ & 0.09 & - & - & - & 0.36 & 0.90 & 0.81 & 1 \\
\hline Water depth & 0.05 & - & - & - & -0.67 & -0.87 & 0.93 & 2 \\
\hline
\end{tabular}




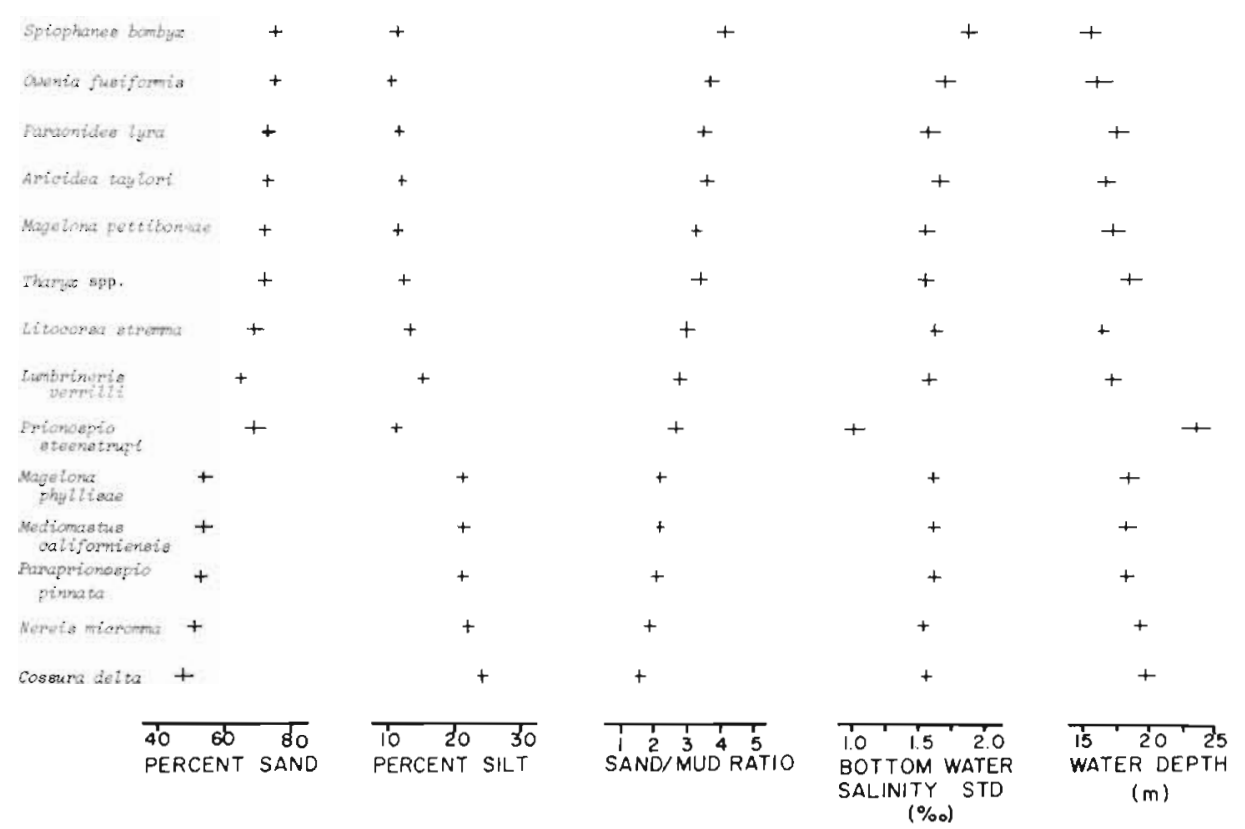

Fig. 2. Mean and $95 \%$ confidence interval for those environmental variables that characterize each polychaete species niche. These variables were identified from discriminant analysis (Table 2)

ing variable on $\mathrm{DF} 2$. The remaining three environmental variables of the original eight-variable set had low standardized coefficients which did not contribute to the separation of species and thus were not included in Table 2 .

In summary, species positions on DF1 can be regarded as a response to either a sandy or a silty environment. On DF2 the species' response is to water depth and the degree of environmental stability as reflected by salinity STD. These results suggest that Cossura delta prefers a siltier bottom environment than the other species (Fig. 2), which tends to segregate its niche space from the others (Fig. 1). At the opposite end of the spectrum, Spiophanes bombyx inhabits very sandy sediments and lives in relatively shallow water depths (Fig. 2), characteristics which also tend to segregate it from the others. The niche space for Prionospio steenstrupi was also segregated from the other polychaetes (Fig. 1). This species lives in deeper water with more bottom water environmental stability as illustrated by a lower salinity STD (Fig. 2). The nonoverlap between any of the above species' confidence ellipses with any other species reveals that these three polychaetes significantly differ in their positions in the discriminant space.

Further inspection of Figure 1 reveals that the remaining polychaetes cluster into three dinstinct areas of discriminant space. Paraonides Iyra, Magelona pettiboneae, Aricidea taylori, Tharyx spp., Litocorsa stremma and Owenia fusiformis formed one cluster because they are found in sandy sediments (more than $65 \%$ ) with a relatively low mud content (Fig. 2). A second cluster, Paraprionospio pinnata, Magelona phyllisae, Nereis micromma and Mediomastus californiensis, occupied niche positions on the siltier side of the discriminant space (Fig. 1). This group lives in habitats usually characterized by less than $60 \%$ sand, but more poorly sorted sediments, consistently more silty (Fig. 2). These polychaetes are usually found in the mid-depth range of the stations examined. The final cluster includes only Lumbrineris verrilli which is positioned in discriminant space between the fauna of the sandier habitats and the fauna of siltier habitats. This species appears to prefer habitats with a mean of no more than $15 \%$ silt (65\% sand) in the sediments (Fig. 2).

It should be pointed out that the separation observed between species is separation on the basis of the environmental variables measured in this study and those used in the analysis. Separation between species niches could actually be greater for any pair of these polychaetes species because additional variables not measured may provide additional basis for segregation. The significant separation observed here between species does not necessarily imply causality because, as Green (1974) noted, statistical evidence from discriminant analysis alone is insufficient to indicate causality.

\section{Niche Overlap and Specialization}

Niche overlap between two species means that they utilize a joint or shared resource (Levins, 1968). To measure niche overlap for the abundant polychaetes in 


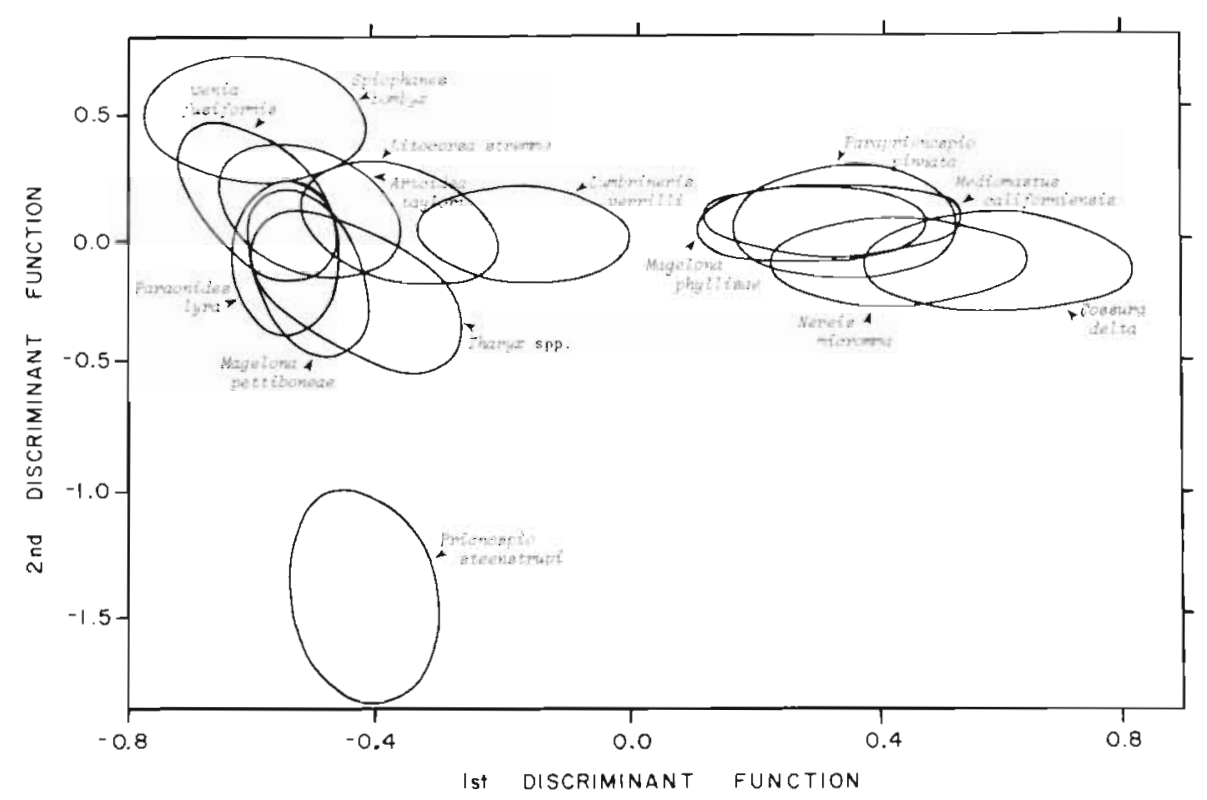

Fig. 3. Ninety-five percent confidence ellipses for the polychaete species' individual discrimirant scores on discriminant Functions 1 and 2. These confidence regions were calculated from the discriminant score means, variances and covariances using the principal axis technique of Sokal and Rohlf (1969)

the south Texas nearshore benthos, we calculated the $95 \%$ confidence ellipse for the discriminant score for each species on DF1 and DF2 according to Dueser and Shugart (1979). These ellipses (Fig. 3) are interpreted as the multidimensional utilization of space defined by the measured variables of the benthic habitat and provide a simple concept of habitat overlap.

As might be expected, the greatest amount of overlap occurs within each of the three species clusters described earlier. Nereis micromma illustrates the greatest overlap (Fig. 3), utilizing habitats of all the other members of its original cluster (Fig. 1) as well as habitat space of Cossura delta. Mediomastus californiensis exhibits overlap with both Paraprionospio pinnata and Magelona phyllisae.

The polychaetes inhabiting the sandier habitat also show a great deal of niche overlap among themselves. From this group Litocorsa stremma is the only one to overlap with Lumbrineris verrilli (Fig. 3). Spiophanes bombyx, the polychaete selecting not only the sandiest habitats but also the shallowest, displays niche overlap with Owenia fusiformis and Aricidea taylori. The illustrations of overlap detailed above only apply to habitat preferences and do not imply that direct competition is occurring between the species.

In contrast to the above, Prionospio steenstrupi, although showing a large dimension to its habitat space, does not exhibit overlap with any other polychaetes (Fig. 3). It is unique in its habitat choice, preferring slightly deeper water, possibly because of this habitat's more stable bottom water environment coupled with sandier sediments (Fig. 2).
Niche breadth, as defined by the works of both Schoener (1968) and Dueser and Shugart (1979), refers to the utilization of a niche dimension, and the extent of this breadth reflects the specialization of the species in exploiting the characteristics of this dimension. Numerous means of measuring niche breadth and interpreting its meaning exist (e. g. Green, 1971; M'Closky, 1976). We used the methods of Dueser and Shugart (1979) to incorporate niche position (d), distance away from the average habitat, degree of specialization $(V)$, the relative variability in this distance and a direct estimate of niche breadth, and expected population abundance in an optimal habitat (a) of the 14 polychaetes into a conceptual model of the community niche pattern.

The three-dimensional representation of the three community niche pattern characteristics $\bar{d}, V$, and a (Fig. 4), illustrates that a relatively consistent trend occurs between $\bar{d}$ and $V$, niche position and niche breadth (inverse relationship). As $\bar{d}$ increases in value, implying a greater degree of species exploitation specialty in moving greater distance from the average habitat (Dueser and Shugart, 1979), the niche breadth often decreases.

A number of polychaetes including Lumbrimeris verrilli, Magelona phyllisae, Paraprionospio pinnata and Mediomastus californiensis, occupy habitats closer to the average as indicated by their lower values for $\bar{d}$ (Fig. 4). These species can be considered generalists because they have greater variability in niche configuration (high $V$ ) and are more abundant at the optimal habitat sites. 


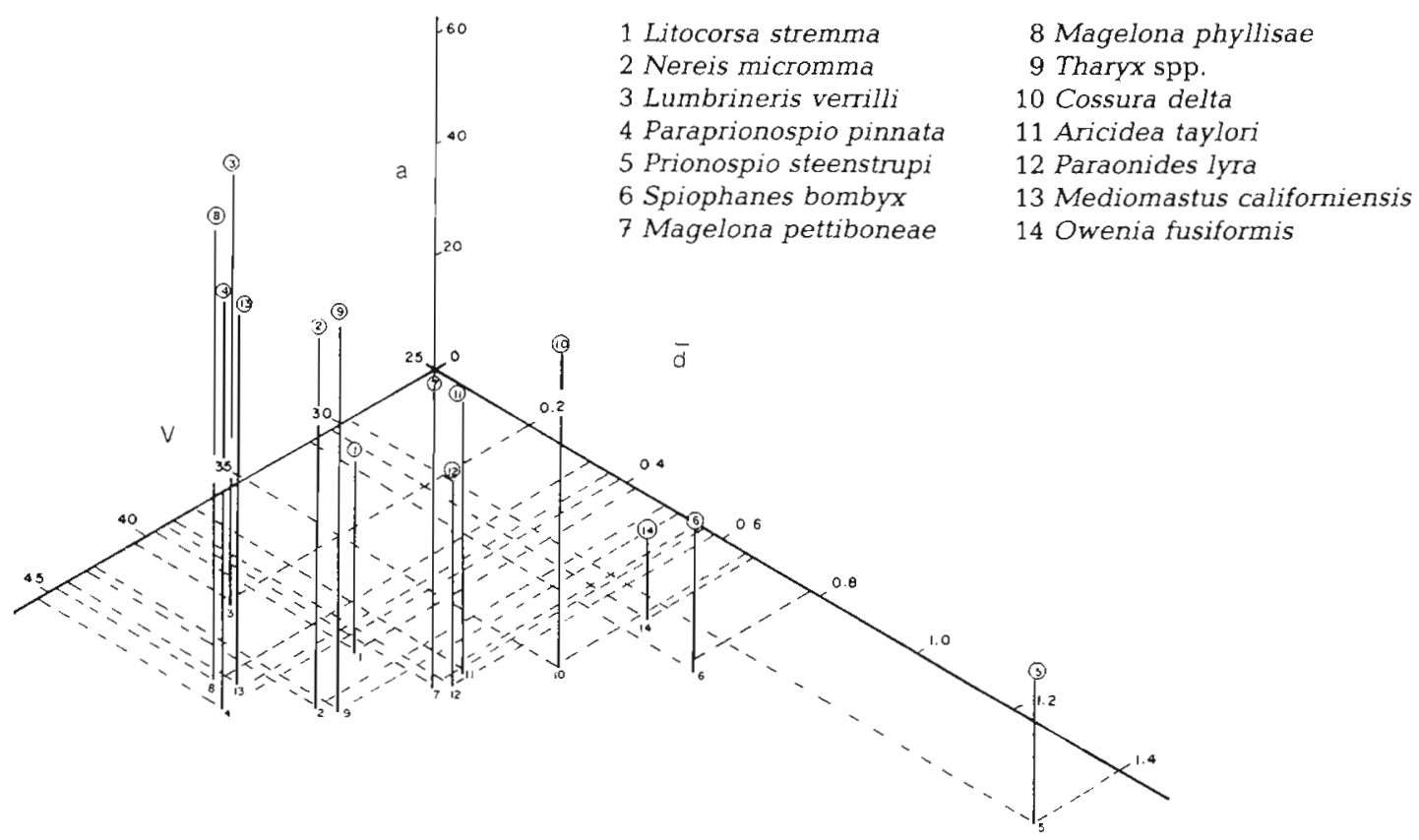

Fig. 4. General niche pattern for the polychaete fauna of the south Texas shelf benthos. The niche pattern incorporates measures of niche position $(\bar{d})$, relative niche breadth ( $V$ and population abundance in optimal habitat (a). See Dueser and Shugart (1979) for calculation of the parameters

In contrast, a few species including Prionospio steenstrupi, Spiophanes bombyx and Owenia fusiformis exhibit much larger values of $\bar{d}$ and relatively smaller abundances as well as a much smaller niche breadth (V). This suggests that these species, occupying more extreme positions (high $\bar{d}$ ), with less niche configuration variability (low $V$ ) and smaller abundances, can be classed as specialists because they are found at the fringes of the average habitat sampled and exhibit a more restricted preference for their habitat characteristics.

\section{DISCUSSION}

The preceding multivariate environmental discriminant analysis completely separated several distinct polychaete species clusters (Fig. 1) within a community structure that until now has been defined as relatively similar over a broad geographic region of the south Texas continental shelf (Flint and Rabalais, 1980). These groups were separated according to their preference for a certain sediment grain size as well as their selection for different degrees of stability of the bottom water environment, which was related to the water depth they inhabited. The position of each of these groups in discriminant space provides a subjectively valid physical description of the structural niche for that group. The definition of these distinct polychaete niches indicates a microstructure to a benthic environment that was previously thought to be relatively homogeneous in species assemblages. It is probable that these niche patterns reflect both ecological and evolutionary adjustments to competition (Dueser and Shugart, 1979) between the species. M'Closky (1976) has speculated that structural habitat division by rodents was one of the means by which coexistence in the same general community was achieved.

Although the above explains the ability to coexist for the distinct clusters, one must ask what mechanisms allow the species within a cluster to coexist (e.g. Mediomastus californiensis, Paraprionspio pinnata, Magelona phyllisae, and Nereis micromma), especially in such high densities and when there is considerable niche overlap (Fig. 3). M'Closky (1976) speculated that coexistence may also be correlated with other niche dimensions, besides environmental factors, such as food sources. A recent review of polychaete feeding strategies (Fauchald and Jumars, 1979) has provided the information necessary to classify the polychaetes observed in this study according to their means of obtaining food from the benthos and the position within the vertical extent of the bottom sediments that these various strategies of food gathering allow them to inhabit. Although Fauchald and Jumars' predictions of feeding habits are in the form of hypotheses, the use of this additional information provides us with further potential evidence that these species occupy different niches. 


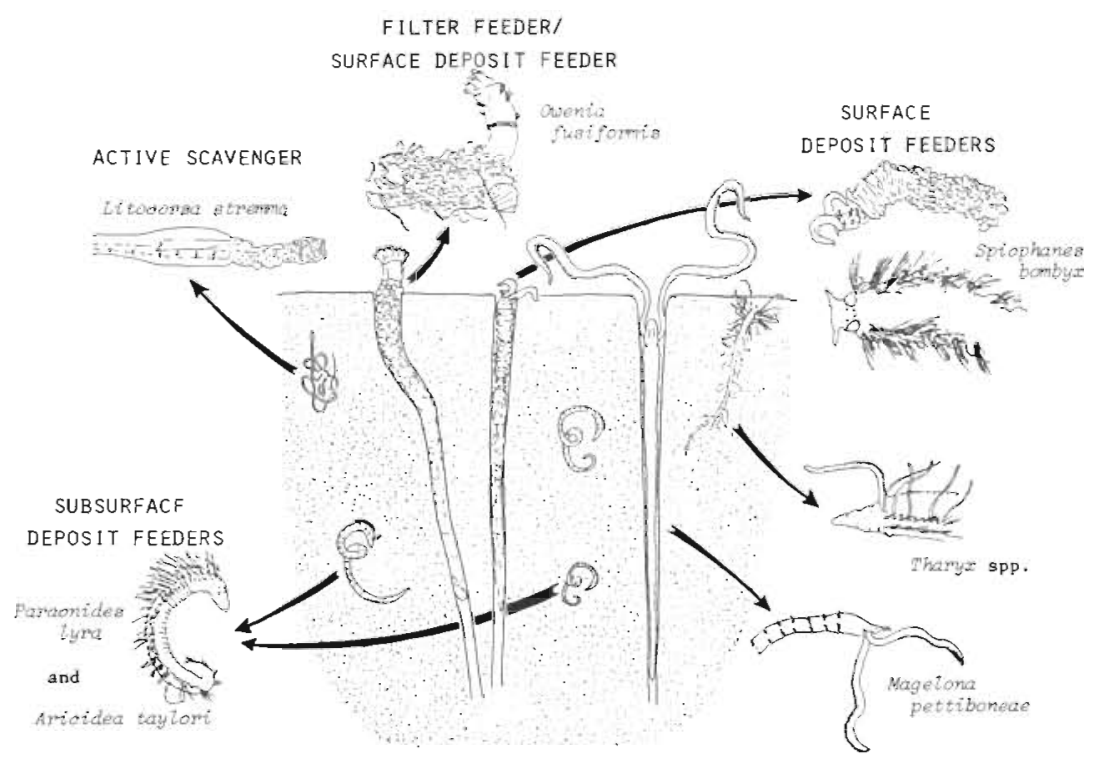

Fig. 5. Conceptual model of feeding strategies and position within the sediment where polychaete species exhibiting similar environmental preferences in Figure 1 derive their nutrition

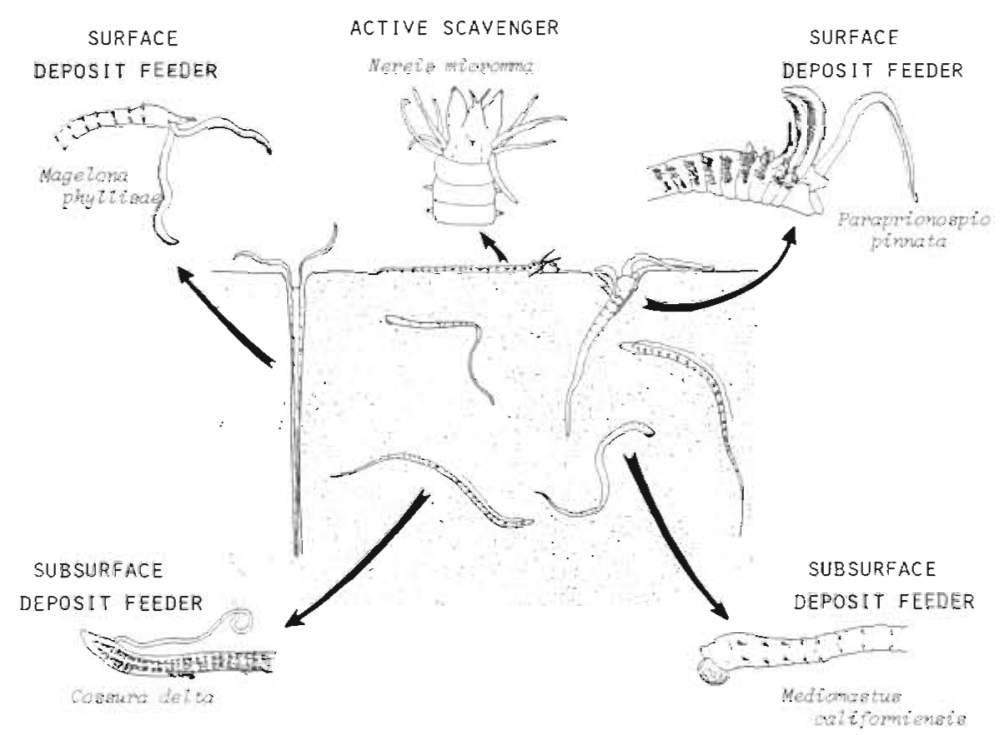

Fig. 6. Conceptual model of feeding strategies and position within the sediment where polychaete species exhibiting similar environmental preferences in Figure 1 derive their nutrition

For example, if we examine the seven polychaetes that indicate a preference for sandier bottom habitats according to their various feeding strategies, a further very obvious division of the habitat structure is observed (Fig. 5). Owenia fusiformis, with its lobed tentacular crown of ciliary paths, is capable of both filter feeding and of surface deposit feeding. These tubicolous worms can feed in an upright position or bend over towards the substratum. Spiophanes bombyx, Tharyx spp. and Magelona pettiboneae, which also inhabit the surface sediments, are surface deposit feeders but are more motile than $O$. fusiformis.
Spiophanes lives in a loosely constructed tube which it is capable of leaving, and Tharyx and Magelona are good burrowers, without distinct tubes. The structure of the feeding apparatuses in all of these indicates the potential for high levels of selectivity both in particle size and composition, thus further dividing their food resources.

Another division of the habitat is observed with the feeding strategies exhibited by Paranoides lyra and Aricidea taylori. These species are classified as subsurface deposit feeders and as such inhabit the deeper sediment layers, further removing them from the same 
realized niche as the other polychaetes of this group. Not enough is known of the feeding modes of these closely related species to further segregate their niches. Litocorsa stremma, because of its active scavenging as hypothesized by Pearson (1970), does not require a further distinction of habitat separation to eliminate competition.

A similar refinement of habitat structuring according to feeding strategies can be accomplished for the other major species cluster illustrated in Figure 1. Again, there is a differentiation of position within the habitat between the surface deposit feeders (Magelona phyllisae and Paraprionospio pinnata) and the subsurface deposit feeders (Cossura delta and Mediomastus californiensis) with the active scavenger Nereis micromma, a higher member of the trophic web (Fig. 6), thus eliminating it from competition with the others.

Another interesting pattern concerning the polychaetes examined in this study concerns species that are both morphologically and functionally (feeding strategies) similar. These include Paraprionospio pinnata, Prionospio steenstrupi and Spiophanes bombyx as well as Magelona phyllisae and $M$. pettiboneae. In all cases these morphologically and functionally similar polychaete pairs (Figs. 5 and 6) structurally divide their habitat by the preferences they show for either sediment type and/or bottom water environmental stability (Fig. 1). Although Paraonides lyra and Aricidea taylori are also morphologically and functionally similar, they did not show a further niche segregation based on habitat preference. As stated above, however, because not enough is known concerning the behavior of these two species, there may still be something present in their ecology that further distinguishes their niches.

In summary, the infaunal polychaete species of the shallow south Texas continental shelf exhibit a pattern of niche structure that allows one to speculate on their various roles in the community, beyond the confines of a general community structure evaluation. From an assemblage of species that were considered relatively similar over a wide geographic area of the shelf benthic habitat we are now able to hypothesize on the structural division of this habitat by these various species, based upon their preference for a certain characteristic environment. Although other investigators have shown that interactions occur between marine infaunal species occupying the same habitat (e.g. Rhoads and Young, 1970; Woodin, 1976; Whitlatch, 1977; Weinberg, 1979), the information contained here illustrates how relatively similar species in the same habitat can minimize these interactions in order to persist.

Furthermore, the polychaetes of this environment can be described as either generalists or specialists within this habitat based upon their position in the discriminant space describing that habitat. We can hypothesize that those species some distance from the average habitat sampled during this study are acting as specialists within the benthos and are probably much more poorly adapted to the general environmental characteristics of the south Texas shelf ecosystem. In contrast, a number of polychaetes occupy nearaverage niche position (low $\bar{d}$ ) with great variability in niche configuration (high $V$ ) and high abundance (Fig. 4). These fauna are considered generalists in the habitat sampled because of their ubiquitous nature. These niche patterns, especially for Paraprionospio pinnata, Mediomastus californiensis, and Magelona phyllisae, are consistent with the broad distribution and environmental diversity of these species observed elsewhere in south Texas marine and estuarine waters (Flint and Holland, 1980; Flint and Rabalais, 1980; Flint et al., 1980) as well as in other continental shelf and estuarine habitats (Dauer and Simon, 1976; Boesch et al., 1976; Holland et al., 1977).

By going one step further and examining the functional role that these species perform within their habitat, we have been able to further differentiate the structural separation of the south Texas shallow water shelf benthos by a diverse group of fauna. We have shown that feeding strategies of the polychaetes examined act as an additional potential mechanism in further dividing the structural niche of fauna that are otherwise very similar in their environmental preferences.

Acknowledgements. We wish to thank all of the staff participants who aided in the taxonomy and enumeration of these species from 1976-1977. Additional thanks are expressed to those who participated in the extensive field sampling program. D. Kalke and L. Tinnin assisted in preparing the final manuscript. This research was supported by the Bureau of Land Management under Contract No. AA551-CT8-51 to the University of Texas.

\section{LITERATURE CITED}

Bernstein, B. B., Hessler, R. R., Smith, R., Jumars, P. A. (1978). Spatial dispersion of benthic Foraminifera in the abyssal central North Pacific. Limnol. Oceanogr. 23 (3): 401-416

Boesch, D. F., Diaz, R. J., Virnstein, R. W. (1976). Effects of tropical storm Agnes on soft-bottom macrobenthic communities of the James and York estuaries and the lower Chesapeake Bay. Chesapeake Sci. 17: 246-259

Buchanan, J. B., Kain, J. M. (1971). Measurement of physical and chemical environment. In: Holme, N. A., McIntyre, A. D. (eds) Methods for study of marine benthos. Blackwell Scientific Publications, Oxford, pp. 33-45 (IBP Handbook No. 16)

Cody, M. L. (1968). On the methods of resource division in grassland bird communities. Am. Nat. 102: 107-137 
Cooley, W. W., Lohnes, P. R. (1971). Multivariate data analysis, Wiley, New York

Dauer, D. M., Simon, J. L. (1976). Habitat expansion among polychaetous annelids repopulating a defaunated marine habitat. Mar. Biol. 37: 169-177

Dueser, R. D., Shugart, H. H., Jr. (1978). Microhabitats in a forest-floor small mammal fauna. Ecology 59: 89-98

Dueser, R. D., Shugart, H. H. (1979). Niche pattern in a forestfloor small-mammal fauna. Ecology 60: 108-118

Fauchald, K., Jumars, P. (1979). The diet of worms: A study of polychaete feeding guilds. Oceanogr. mar. Biol. Ann. Rev. 17: 193-284

Flint, R. W., Holland, J. S. (1980). Benthic infaunal variability on a transect in the Gulf of Mexico. Estuar. Coast. Mar. Sci. 10: 1-14

Flint, R. W., Rabalais, N. N. (eds) (1980). Environmental studies, south Texas outer continental shelf, 1975-1977. Vol. I. Ecosystem description. Final rep. to Bureau of Land Management, Washington, D.C. Contract AA551-CT8-51 by the Univ. of Texas, Mar. Sci. Inst., pp. 123-138

Flint, R. W., Poff, M., Younk, J. A. (1980). A benthic infaunal survey of the Corpus Christi Ship Channel area near Ingleside, Texas. Final rep. to Natural Gas and Pipeline Co. of America, Chicago, Ill. by Univ. of Texas, Mar. Sci. Inst., $76 \mathrm{pp}$

Green, R. H. (1971). A multivariate statistical approach to the Hutchinsonian niche: bivalve molluscs of central Canada. Ecology 52: 543-556

Green, R. H. (1974). Multivariate niche analysis with temporally varying environmental factors. Ecology 55: 73-83

Green, R. H. (1977). Some methods for hypothesis testing and analysis with biological monitoring data. In: Cairns, J., Dickson, K. L., Westlake, G. F. (eds) Biological monitoring of water and effluent quality. ASTM STP 607, American Society for Testing and Materials, pp. 200-211

Holland, A. F., Mountford, N. K., Mikursky, J. A. (1977). Temporal variation in upper bay mesohaline benthic communities. I. The 9-m mud habitat. Chesapeake Sci. 18: 370-378

Hutchinson, G. E. (1957). Concluding remarks. Cold Spring Harbor Symposium in Quantitative Biology 22: 415-427

Knight, G. S. (1974). Benthic community structure in Lyttelton Harbour, N. J. J. mar. Freshw. Res. 8: 291-306
Levins, R. (1968). Evolution in changing environments. Princeton University Press, Princeton, New Jersey, USA

MacArthur, R. H. (1968). The theory of the niche. In: Lewontin, R. C. (ed.) Population biology and evolution. Syracuse University Press, Syracuse, New York, USA, pp. 158-176

Maguire, B., Jr. (1967). A partial analysis of the niche. Am Nat. $101: 515-523$

Makarewicz, J. C., Likens, G. E. (1975). Niche analysis of zooplankton community. Science, N. Y. 190: 1000-1003

Mattson, J. S., Mattson, C. S., Spencer, S. A., Sparks, S. A. (1977). Multivariate statistical approach to the fingerprinting of oils by infrared spectrometry. Anal. Chem. 49; 297-302

M'Closky, R. T. (1976). Community structure in sympatric rodents. Ecology 57: 728-739

Pearson, T. H. (1970). Litocorsa stremma a new genus and species of pilargid (Polychaeta: Annelida) from the west coast of Scotland, with notes on two other pilargid species. J. nat. Hist. 4: 69-77

Rabalais, N. N., Holt, S. A., Flint, R. W. (in press). Mud shrimps (Crustacea, Decapoda, Thalassinidea) of the northwestern Gulf of Mexico. Bull. mar. Sci. 31 (1)

Rhoads, D. C., Young, D. K. (1970). The influence of depositfeeding organisms on sediment stability and community trophic structures. J. mar. Res. 28: 150-170

Schoener, T. W. (1968). The Anolis lizards of Bimini; resource partitioning in a complex fauna. Ecology 49: 702-726

Sokal, R. R., Rohlf, F. J. (1969). Biometry, W. H. Freeman and Company, San Francisco, Calif., USA

Weinberg, J. R. (1979). Ecological determinants of spionid distributions within dense patches of deposit-feeding polychaete Axiothella rubrocincta. Mar. Ecol. Prog. Ser, 1: 301-314

Whitlatch, R. B. (1977). Seasonal changes in the community structure of the macrobenthos inhabiting the intertidal sand and mudflats of Barnstable Harbor, Massachusetts. Biol. Bull. mar. biol. Lab., Woods Hole 152: 275-294

Whittaker, R. H., Levin, S. A., Root, R. B. (1973). Niche, habitat and ecotope. Am. Nat. 107: 321-338

Woodin, S. A. (1976). Aduit-larval interactions in dense infaunal assemblages: Patterns of abundance. J. mar. Res. 34 $25-41$ 